\title{
Assessment of the Effects of Poultry Litter on Surface Runoff Water Quality from Agricultural Lands
}

\author{
Sudarshan K. Dutta ${ }^{{ }^{*}}$, Shreeram P. Inamdar ${ }^{2}$, J. Tom Sims ${ }^{1}$, Alyssa Collins ${ }^{1}$ \\ ${ }^{1}$ Plant and Soil Sciences, College of Agricultural and Natural Resources, University of Delaware, Newark, USA \\ ${ }^{2}$ Bioresources Engineering, College of Agricultural and Natural Resources, University of Delaware, Newark, USA \\ E-mail:sdutta@udel.edu \\ Received November 14, 2009; revised December 16, 2009; accepted April 2, 2010
}

\begin{abstract}
The use of pelletized poultry litter (PPL) as a substitute for inorganic fertilizers is increasingly being encouraged in states like Delaware which have a considerable surplus of poultry litter. However, we know very little about the impacts of PPL on runoff water quality and whether it is an environmentally-sound and sustainable alternative to inorganic fertilizer. To address these questions we compared the exports of nutrients $\left(\mathrm{NH}_{4}-\mathrm{N}, \mathrm{NO}_{3}-\mathrm{N}\right.$ and $\left.\mathrm{PO}_{4}-\mathrm{P}\right)$ and trace elements $(\mathrm{As}, \mathrm{Cu}$, and $\mathrm{Zn})$ in surface runoff from agricultural plots receiving PPL, raw poultry litter (RPL), urea and no-fertilizer (control) treatments. The study was conducted on agricultural land located in Middletown, Delaware with corn as the cover crop. The experimental plots were $5 \mathrm{~m}$ wide and $12 \mathrm{~m}$ long with reduced tillage and no-tillage management practices. Sampling was conducted for six natural rainfall events from April through August 2008. Nutrient $\left(\mathrm{NH}_{4}-\mathrm{N}, \mathrm{NO}_{3}-\mathrm{N}\right.$ and $\left.\mathrm{PO}_{4}-\mathrm{P}\right)$ exports from plots receiving PPL were less than those with urea or raw litter applications. While exports of trace elements from the PPL treatment exceeded those from urea, they were much lower than the corresponding exports from the RPL treatments. Mass exports of nutrients and trace elements were correlated with event size (rainfall amount) but were not correlated with timing of event (days since litter application). Results from this study suggest that the use of PPL in combination with no-tillage may provide an environmentally safe alternative to synthetic fertilizers.
\end{abstract}

Keywords: Poultry Litter, Surface Runoff, Water Quality, Tillage, Best Management Practices, Nutrients, Trace Elements

\section{Introduction}

Increasing costs of synthetic fertilizers has resulted in many farmers adopting animal manure and poultry litter/wastes as substitutes for synthetic fertilizers. This is especially true for states like Delaware that have a large surplus of poultry waste associated with a large poultry industry. The use of poultry litter as an alternative to commercial fertilizers is promising as it simultaneously addresses the issues of rising costs of inorganic fertilizer and disposal of waste from animal operations. To encourage the use of poultry litter as fertilizer, pelletizing plants that convert raw poultry litter (RPL) to a dry, pelletized form, are also being introduced. Pelletized poultry litter (PPL) is much more amenable to transport and land-application than its raw counterpart. However, currently we know very little about how the application of poultry litter in either form on agricultural land impacts runoff water quality. Non-point source pollution from agricultural land is an existing concern and we must ensure that large-scale adoption of animal wastes as fertilizer on croplands does not worsen the problem. In addition to nitrogen and phosphorus, poultry litter also contains trace elements like arsenic (As), copper $(\mathrm{Cu})$, and zinc $(\mathrm{Zn})$ which are often added to poultry feed to increase weight, improve feed efficiency and egg production, and prevent diseases $[1,2]$. Thus, to evaluate the use of raw and pelletized poultry litter as environmentally-safe alternatives to synthetic fertilizers it is critical to investigate the potential for exports of nutrients and trace elements in runoff from such applications.

To date, most of the studies that have investigatedpoultry litter have focused on runoff water quality from 
pasture lands [3-7]. Haggard et al. [4] evaluated nutrient loss in surface runoff from fescue-Bermuda grassclover plots in Fayetteville, Arkansas by applying six different forms of poultry manures including raw and pelletized litter. They found that the runoff concentrations of ammonium- $\mathrm{N}\left(\mathrm{NH}_{4}-\mathrm{N}\right)$, nitrate- $\mathrm{N}\left(\mathrm{NO}_{3}-\mathrm{N}\right)$, and soluble reactive $\mathrm{P}$ (SRP) were higher for plots receiving raw poultry litter versus those receiving pelletized litter. Ammonium-N, $\mathrm{NO}_{3}-\mathrm{N}$, and SRP concentrations in surface runoff corresponding to pelletized litter were $15.9,0.4$ and $12 \mathrm{mg} / \mathrm{L}$, respectively while those for raw litter were $22,7.3$ and $15.1 \mathrm{mg} / \mathrm{L}$, respectively. The mass exports of $\mathrm{NH}_{4}-\mathrm{N}$ were also greater from the plots receiving RPL ( $15 \mathrm{~g} / \mathrm{ha})$ versus those receiving PPL (7 g/ha). In another study conducted on fescue grass plots with simulated rainfall conditions, Edwards and Daniel [3] reported that the concentrations of $\mathrm{NH}_{4}-\mathrm{N}$ in runoff water were nearly doubled (66 to $114.3 \mathrm{mg} / \mathrm{L}$ ) when the application rate of poultry litter was doubled (218 to $435 \mathrm{~kg} \mathrm{~N} / \mathrm{ha}$ ). Similarly, concentrations of $\mathrm{NO}_{3}-\mathrm{N}$ and total $\mathrm{P}(\mathrm{TP})$ also increased when the application rate of poultry litter was doubled [3]. Concentrations of trace elements $(\mathrm{Cu}$ and $\mathrm{Zn})$ in runoff water have also been found to increase following applications of poultry litter [7].

In comparison to pasture, little information is available on the exports and concentrations of nutrients and trace elements from croplands receiving raw or pelletized litter applications. We especially know little about how tillage practices impact the export potential of nutrients and trace elements from fields receiving litter application. Furthermore, most previous studies have been conducted under simulated rainfall conditions which typically use single rainfall intensity and only a few pouring events; very little data is available for natural rainfall events. Our interest in this study was to evaluate the exports of nutrients $\left(\mathrm{NH}_{4}-\mathrm{N}, \mathrm{NO}_{3}-\mathrm{N}\right.$ and $\mathrm{PO}_{4}-\mathrm{P}$ ) and trace elements (As, $\mathrm{Cu}$, and $\mathrm{Zn}$ ) in surface runoff from agricultural plots receiving PPL, RPL, and urea. Sampling was performed for six natural rainfall events occurring over a four month period in AprilAugust, 2008. In addition to nutrients and trace elements, mass exports of dissolved organic carbon (DOC) in surface runoff were also evaluated to investigate the influence of DOC on the transport and exports of trace elements. Specific questions that were addressed included: How do nutrient and trace element exports in surface runoff from plots receiving PPL and RPL compare against those receiving urea applications? How does the tillage practice (reduced versus no-tillage) influence the exports? What is the impact of individual storm events (amount and timing after litter application) on the exports of nutrients and trace elements?

\section{Materials and Methods}

\subsection{Site Description and Experimental Design}

The study was conducted on experimental plots located on cropland adjacent to the campus of St. Andrew's School in Middletown, New Castle County, Delaware $\left(39.45^{\circ} \mathrm{N}, 75.69^{\circ} \mathrm{W}\right)$. The experimental plots were aligned North-South and were located on Matapeake silt-loam soil with a slope gradient of $2-5 \%$. The soil is classified as fine-silty, mixed, mesic typic hapludults [8]. Average annual precipitation for the county is $1130 \mathrm{~mm}$ with highest monthly precipitation typically occurring in August [9]. Precipitation during the summer is associated with low-pressure systems from the south which produce high-intensity convective storm events. Average annual temperature is $12^{\circ} \mathrm{C}\left(54^{\circ} \mathrm{F}\right)$ with maximum temperatures typically occurring during the latter part of July. Ten experimental plots $(5 \mathrm{~m}$ wide $\times 12 \mathrm{~m}$ long) with five each in reduced and no-tillage treatments were established. The experimental design was a $5 \times 2$ factorial arranged in a randomized block design. Fertilizer applications for each treatment block (reduced or no-tillage) included-PPL, RPL (high and moderate rate), urea, and no-fertilizer (control). The "reduced tillage" plots in our experiment were conventionally tilled until September 2007; however in 2008 the farmer switched to no-tillage practice for these plots. Thus, since these plots were in a transition phase from conventional tillage to no-tillage we classified them as reduced tillage. In comparison, the no-tillage plots had not been tilled for a period of more than three years. PPL and urea were applied to provide $252 \mathrm{~kg} / \mathrm{ha}$ of plant available nitrogen which resulted in an application rate of $12.6 \mathrm{Mg} / \mathrm{ha}$ for PPL and 0.547 $\mathrm{Mg} / \mathrm{ha}$ for urea. Raw poultry litter was applied at moderate $($ RPL1 $=23 \mathrm{Mg} / \mathrm{ha})$ and high rates $(\mathrm{RPL} 2=35$ $\mathrm{Mg} / \mathrm{ha}$ ). Urea and all litter applications occurred during the third week of April 2008. The crop on the plots was corn with planting occurring in the second week of April, 2008.

\subsection{Sampling and Analysis}

The experimental plots were enclosed with plastic edges to constrain surface runoff within the plots. A sampling bucket $(37.85 \mathrm{~L})$ fitted with PVC pipes was established in a pit at the lower end of each plot to collect surface runoff from the plots. Samples were collected for six rainfall events over the April-August, 2008 study period (Table 1 and Figure 1). Rainfall and weather data were available from a climate station located in Middletown, Delaware [10]. The amount of surface runoff collected in the bucket was recorded following each event. Prior to sampling, the water in the bucket was thoroughly stirred to get a representative sample of runoff water. After col- 
Table 1. Amounts, dates, and days since litter application for the monitored six natural rainfall events.

\begin{tabular}{ccccccc}
\hline Event \# & 1 & 2 & 3 & 4 & 6 & July 4-6 \\
\hline Date of event & April 27-29 & May 8-10 & May 11-13 & June 3-6 & 23, 24 \\
$\begin{array}{c}\text { Total Rainfall (mm) } \\
\text { Days Since Litter } \\
\text { Application }\end{array}$ & 27.9 & 71.1 & 69.1 & 42.2 & 41.4 \\
\hline
\end{tabular}

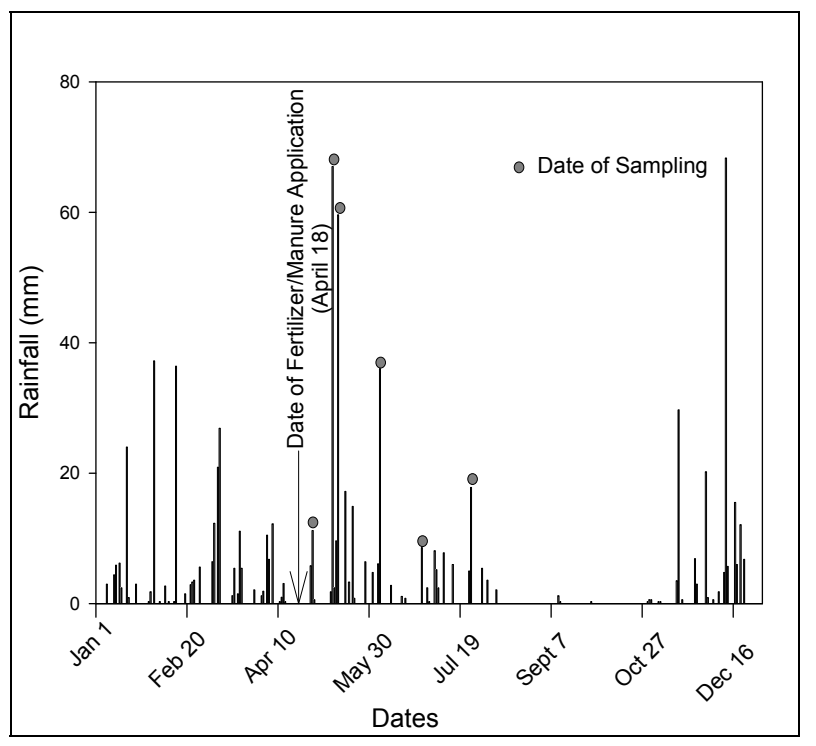

Figure 1. Rainfall amounts for storm events in the year 2008. Events sampled in this study during April-August 2008 are indicated by filled circles.

lection of samples, the sampling buckets were then emptied and cleaned. Runoff samples were collected in 250 $\mathrm{mL}$ HDPE bottles for each bucket. Runoff water were then filtered through $0.45 \mu \mathrm{m}$ membrane filter paper (Millipore Corp., Billerica, MA), and stored at $4^{\circ} \mathrm{C}$ until analyses. Prior to storage, water samples were also analyzed for $\mathrm{pH}$ and total dissolved solids (TDS) at $25^{\circ} \mathrm{C}$ with an Accumet AP85 pH/Conductivity/TDS Meter (Fisher Scientific Inc. Hampton, NH). Water samples were analyzed for: ammonium nitrogen $\left(\mathrm{NH}_{4}-\mathrm{N}\right)$, nitrate nitrogen $\left(\mathrm{NO}_{3}-\mathrm{N}\right)$, phosphate phosphorous $\left(\mathrm{PO}_{4}-\mathrm{P}\right)$, arsenic (As), copper $(\mathrm{Cu})$, zinc $(\mathrm{Zn})$ and dissolved organic carbon (DOC). Concentrations of $\mathrm{NH}_{4}-\mathrm{N}$ and $\mathrm{NO}_{3}-\mathrm{N}$ were determined using BRAN + LUEBBE method no. US $696 \mathrm{D}-82 \mathrm{X}$ while $\mathrm{PO}_{4}-\mathrm{P}$ concentrations were determined by colorimetric method (BRAN + LUEBBE method no. US 696A-82W). The trace element concentrations were determined by ICP-AES (HP 4500, Agilent Technologies, Santa Clara, CA). Concentrations for DOC were determined using a Tekmar-Dohrmann Phoenix 8000 total organic carbon analyzer.

Mass exports of nutrients and trace elements in surface runoff were computed by multiplying the concentrations of nutrients and trace elements by the runoff volumes for each of the six events. The t-test was used to determine whether mass exports were significantly different at $\alpha$ level of $10 \%(\mathrm{p} \leq 0.10)$. Flow-weighted concentrations of nutrients and trace elements for each treatment were computed by dividing the total of mass exports for the six events with the corresponding total of runoff water volumes. The influence of storm events on mass exports was determined by calculating the correlations between mass exports and rainfall amounts using the F-test. Correlations were also computed between mass exports and time of occurrence of event (days since application of litter). Data on DOC was available for four of the six storm events. Correlations between mass exports of DOC and nutrients as well as trace elements were also computed. All statistical analyses were performed using Origin Software (version 8E, OriginLab, Inc.).

To establish baseline plot concentrations prior to litter and fertilizer applications, surface soil samples $(0-5 \mathrm{~cm})$ from the plots were analyzed for nutrients and trace elements. In addition, samples of PPL and RPL were also analyzed for nutrient and trace element contents. Soil samples were collected with sampling auger and air dried in the laboratory. Both soil and litter samples were digested and the extracts were analyzed following the procedures used for water analysis (mentioned above). PPL and RPL had higher concentrations of trace elements compared to urea (Table 2). Concentrations of nutrients $\left(\mathrm{NH}_{4}-\mathrm{N}, \mathrm{NO}_{3}-\mathrm{N}\right.$ and $\left.\mathrm{PO}_{4}-\mathrm{P}\right)$ and trace elements (As, $\mathrm{Cu}$ and $\mathrm{Zn}$ ) did not differ significantly among the soil samples from the experimental plots (Table 3).

\section{Results}

\subsection{Surface Runoff Volumes, $\mathrm{pH}$ and TDS across the Treatments}

Rainfall amounts for the six events are presented in Table 1 with the corresponding runoff volumes, $\mathrm{pH}$ and TDS reported in Table 4. The surface runoff volumes were not significantly different ( $p \geq 0.1$, Table 4) among the treatments. We also did not find any significant difference $(p \geq 0.1)$ between the surface runoff volumes from reduced versus no-tillage plots. Runoff volumes were, however, significantly correlated $(\mathrm{p} \leq 0.10$, Table 5) with rainfall amounts. The $\mathrm{pH}$ values for surface runoff also did not differ significantly ( $p \geq 0.10$, Table 4) 
Table 2. Nutrient and trace element composition of pelletized and raw poultry litter $(\mathrm{mg} / \mathrm{kg})$ applied to the plots.

\begin{tabular}{ccccccc}
\hline Fertilizer Type & $\mathrm{NH}_{3}-\mathrm{N}$ & $\mathrm{NO}_{3}-\mathrm{N}$ & $\mathrm{PO}_{4}-\mathrm{P}$ & $\mathrm{As}$ & $\mathrm{Cu}$ & $\mathrm{Zn}$ \\
\hline PPL & 5094 & 301 & 183.36 & 0.20 & 0.85 & 0.77 \\
$\mathrm{RPL}$ & 3454 & 218 & 140.26 & 0.45 & 1.06 & 1.55 \\
Urea & $4,50,000$ & 60 & 6.64 & $\mathrm{ND} *$ & $\mathrm{ND}$ & $\mathrm{ND}$ \\
\hline
\end{tabular}

$*$ ND $=$ Non-detectable.

Table 3. Concentrations $(\mathrm{mg} / \mathrm{kg})$ of nutrients and trace elements in surface soils $(0-5 \mathrm{~cm})$ of the experimental plots prior to fertilizer or litter application.

\begin{tabular}{|c|c|c|c|c|c|c|c|}
\hline Tillage type & Applications & $\mathrm{NH}_{3}-\mathrm{N}$ & $\mathrm{NO}_{3}-\mathrm{N}$ & $\mathrm{PO}_{4}-\mathrm{P}$ & As & $\mathrm{Cu}$ & $\mathrm{Zn}$ \\
\hline \multirow{5}{*}{$\begin{array}{l}\text { Reduced } \\
\text { Tillage }\end{array}$} & PPL & 5.4 & 3.5 & 129 & 0.02 & 2.2 & 25 \\
\hline & RPL1 & 3.3 & 3.9 & 99 & 0.37 & 1.0 & 24 \\
\hline & RPL2 & 3.7 & 4.2 & 109 & 0.35 & 1.1 & 26 \\
\hline & Urea & 8.3 & 6.2 & 104 & 0.35 & 1.2 & 25 \\
\hline & Control & 5.6 & 4.5 & 97 & 0.32 & 1.2 & 20 \\
\hline \multirow{5}{*}{ No Tillage } & PPL & 5.3 & 4.3 & 114 & 0.34 & 1.7 & 17 \\
\hline & RPL1 & 4.4 & 7.6 & 92 & 0.30 & 1.1 & 14 \\
\hline & RPL2 & 1.8 & 5.9 & 104 & 0.24 & 1.0 & 24 \\
\hline & Urea & 1.8 & 3.9 & 92 & 0.15 & 1.1 & 17 \\
\hline & Control & 4.7 & 6.4 & 112 & 0.21 & 1.3 & 31 \\
\hline
\end{tabular}

Table 4. Mean runoff volumes (L), $\mathrm{pH}$, total dissolved solids (TDS) corresponding to various treatments for the six storm events.

\begin{tabular}{|c|c|c|c|c|c|c|c|c|c|c|}
\hline & \multicolumn{5}{|c|}{ Reduced Tillage } & \multicolumn{5}{|c|}{ No Tillage } \\
\hline & PPL & RPL1 & RPL2 & Urea & Control & PPL & RPL1 & RPL2 & Urea & Control \\
\hline $\begin{array}{l}\text { Mean } \\
\text { Runoff } \\
\text { (L) }\end{array}$ & $\begin{array}{l}12.7 \\
(8.9)\end{array}$ & $\begin{array}{c}29.9 \\
(27.8)\end{array}$ & $\begin{array}{c}32.1 \\
(25.8)\end{array}$ & $\begin{array}{c}20.2 \\
(18.1)\end{array}$ & $\begin{array}{c}16.0 \\
(15.1)\end{array}$ & $\begin{array}{c}15.0 \\
(11.2)\end{array}$ & $\begin{array}{l}11.1 \\
(7.3)\end{array}$ & $\begin{array}{l}11.0 \\
(7.2)\end{array}$ & $\begin{array}{c}25.4 \\
(22.9)\end{array}$ & $\begin{array}{c}24.3 \\
(23.3)\end{array}$ \\
\hline $\begin{array}{c}\text { Runoff } \\
\%\end{array}$ & 0.20 & 0.37 & 0.40 & 0.26 & 0.21 & 0.20 & 0.15 & 0.15 & 0.32 & 0.31 \\
\hline Mean $\mathrm{pH}$ & $\begin{array}{c}6.45 \\
(0.72)\end{array}$ & $\begin{array}{c}6.16 \\
(0.27)\end{array}$ & $\begin{array}{c}6.24 \\
(0.26)\end{array}$ & $\begin{array}{c}6.39 \\
(0.22)\end{array}$ & $\begin{array}{c}6.29 \\
(0.54)\end{array}$ & $\begin{array}{c}6.31 \\
(0.42)\end{array}$ & $\begin{array}{c}6.67 \\
(0.62)\end{array}$ & $\begin{array}{c}6.67 \\
(0.72)\end{array}$ & $\begin{array}{c}6.69 \\
(0.33)\end{array}$ & $\begin{array}{c}6.44 \\
(0.20)\end{array}$ \\
\hline $\begin{array}{c}\text { Mean } \\
\text { TDS } \\
(\mathrm{ppm})\end{array}$ & $24^{\mathrm{ab}}(15)$ & $60^{\text {ace }}(33)$ & $79^{\text {bdf }}(51)$ & $32^{\text {cd }}(20)$ & $20^{\mathrm{ef}}(10)$ & $37^{g}(18)$ & $59^{g}(62)$ & $60(59)$ & $30(20)$ & $25(7)$ \\
\hline
\end{tabular}

Mean values having the same letters were significantly different at $\mathrm{p} \leq 0.10$ for their corresponding plots; e.g. TDS from PPL plot is significanly different from RPL1 and RPL2 plots under CT management practice. Standard deviations are mentioned within parentheses.

among the treatments. TDS values were significantly different ( $\mathrm{p} \leq 0.10$, Table 4) among the treatments (Table 4). The $\mathrm{pH}$ values varied from 6.16 to 6.69 and the TDS ranged from 20 to $79 \mathrm{ppm}$.

\subsection{Impact of Plot Treatments on Mass Exports of Nutrients and Trace Elements}

Average mass exports and flow-weighted concentrations of nutrients and trace elements for the treatments are reported in Table 6. Mass exports for the individual events are presented in Figures 2-7. While $\mathrm{NH}_{4} \mathrm{~N}$ exports did not differ significantly $(\mathrm{p} \geq 0.10)$ across the treatments (tillage $\times$ treatment), there were differences across the events among the treatments. The large events of May 10 and 13 produced the largest amounts of exports for all treatments. Ammonium-N exports were also slightly different between reduced and no-tillage practices. Under reduced tillage, exports were highest for the RPL2 (RPL2 = $35 \mathrm{Mg} / \mathrm{ha}$ ) treatment for three (May 13, 
Table 5. Correlations (Pearson's) between mass exports of nutrients and trace elements and the rainfall amounts for the six events.

\begin{tabular}{|c|c|c|c|c|c|c|c|c|c|c|}
\hline \multirow{2}{*}{$\begin{array}{l}\text { Constituents } \\
\text { monitored }\end{array}$} & \multicolumn{5}{|c|}{ Reduced Tillage } & \multicolumn{5}{|c|}{ No Tillage } \\
\hline & PPL & RPL1 & RPL2 & Urea & Control & PPL & RPL1 & RPL2 & Urea & Control \\
\hline Runoff & $\begin{array}{l}0.90 * \\
(0.01)\end{array}$ & $\begin{array}{l}0.98^{*} \\
(0.00)\end{array}$ & $\begin{array}{l}0.97 * \\
(0.00)\end{array}$ & $\begin{array}{l}0.95 * \\
(0.00)\end{array}$ & $\begin{array}{l}0.77 * \\
(0.05)\end{array}$ & $\begin{array}{l}0.81 * \\
(0.01)\end{array}$ & $\begin{array}{l}0.97 * \\
(0.00)\end{array}$ & $\begin{array}{l}0.94 * \\
(0.00)\end{array}$ & $\begin{array}{l}0.91 * \\
(0.00)\end{array}$ & $\begin{array}{l}0.59 * \\
(0.05)\end{array}$ \\
\hline $\mathrm{NH}_{3}-\mathrm{N}$ & $\begin{array}{c}0.45 \\
(0.21)\end{array}$ & $\begin{array}{l}0.84 * \\
(0.02)\end{array}$ & $\begin{array}{l}0.81 * \\
(0.03)\end{array}$ & $\begin{array}{l}0.62 * \\
(0.10)\end{array}$ & $\begin{array}{c}0.36 \\
(0.26)\end{array}$ & $\begin{array}{c}0.49 \\
(0.18)\end{array}$ & $\begin{array}{c}0.52 \\
(0.17)\end{array}$ & $\begin{array}{c}0.45 \\
(0.20)\end{array}$ & $\begin{array}{c}0.47 \\
(0.20)\end{array}$ & $\begin{array}{c}0.48 \\
(0.19)\end{array}$ \\
\hline $\mathrm{NO}_{3}-\mathrm{N}$ & $\begin{array}{c}0.45 \\
(0.20)\end{array}$ & $\begin{array}{l}-0.49 \\
(0.97)\end{array}$ & $\begin{array}{l}-0.47 \\
(0.78)\end{array}$ & $\begin{array}{l}0.82 * \\
(0.03)\end{array}$ & $\begin{array}{l}0.77 * \\
(0.04)\end{array}$ & $\begin{array}{l}-0.49 \\
(0.85)\end{array}$ & $\begin{array}{c}0.45 \\
(0.21)\end{array}$ & $\begin{array}{c}0.44 \\
(0.21)\end{array}$ & $\begin{array}{c}0.45 \\
(0.20)\end{array}$ & $\begin{array}{l}0.95^{*} \\
(0.00)\end{array}$ \\
\hline $\mathrm{PO}_{4}-\mathrm{P}$ & $\begin{array}{l}0.95^{*} \\
(0.00)\end{array}$ & $\begin{array}{l}0.94 * \\
(0.00)\end{array}$ & $\begin{array}{l}0.66^{*} \\
(0.09)\end{array}$ & $\begin{array}{c}0.54 \\
(0.15)\end{array}$ & $\begin{array}{c}0.11 \\
(0.39)\end{array}$ & $\begin{array}{c}0.50 \\
(0.17)\end{array}$ & $\begin{array}{l}0.75^{*} \\
(0.05)\end{array}$ & $\begin{array}{l}0.81 * \\
(0.03)\end{array}$ & $\begin{array}{c}0.21 \\
(0.43)\end{array}$ & $\begin{array}{c}0.59 \\
(0.11)\end{array}$ \\
\hline Arsenic & $\begin{array}{c}0.21 \\
(0.43)\end{array}$ & $\begin{array}{l}0.87 * \\
(0.01)\end{array}$ & $\begin{array}{l}0.80 * \\
(0.03)\end{array}$ & $\begin{array}{l}-0.46 \\
(0.77)\end{array}$ & $\begin{array}{l}-0.49 \\
(0.84)\end{array}$ & $\begin{array}{c}0.36 \\
(0.55)\end{array}$ & $\begin{array}{c}0.37 \\
(0.24)\end{array}$ & $\begin{array}{l}0.73 * \\
(0.06)\end{array}$ & $\begin{array}{l}-0.48 \\
(0.86)\end{array}$ & $\begin{array}{l}0.63 * \\
(0.10)\end{array}$ \\
\hline Copper & $\begin{array}{l}0.71 * \\
(0.07)\end{array}$ & $\begin{array}{l}0.98 * \\
(0.00)\end{array}$ & $\begin{array}{l}0.85^{*} \\
(0.02)\end{array}$ & $\begin{array}{l}0.89 * \\
(0.01)\end{array}$ & $\begin{array}{c}0.40 \\
(0.23)\end{array}$ & $\begin{array}{l}0.70 * \\
(0.07)\end{array}$ & $\begin{array}{l}0.78^{*} \\
(0.04)\end{array}$ & $\begin{array}{l}0.93 * \\
(0.04)\end{array}$ & $\begin{array}{c}0.58 \\
(0.13)\end{array}$ & $\begin{array}{l}0.92 * \\
(0.01)\end{array}$ \\
\hline Zinc & $\begin{array}{l}-0.49 \\
(0.99)\end{array}$ & $\begin{array}{l}0.91 * \\
(0.01)\end{array}$ & $\begin{array}{l}0.64 * \\
(0.10)\end{array}$ & $\begin{array}{l}0.64 * \\
(0.10)\end{array}$ & $\begin{array}{l}-0.49 \\
(0.87)\end{array}$ & $\begin{array}{l}0.64 * \\
(0.10)\end{array}$ & $\begin{array}{l}0.65^{*} \\
(0.10)\end{array}$ & $\begin{array}{c}0.57 \\
(0.14)\end{array}$ & $\begin{array}{l}-0.48 \\
(0.87)\end{array}$ & $\begin{array}{l}0.66^{*} \\
(0.09)\end{array}$ \\
\hline
\end{tabular}

The $\mathrm{p}$-values are mentioned within parentheses and numbers indicated by $*$ are significant at $\mathrm{p} \leq 0.10$.

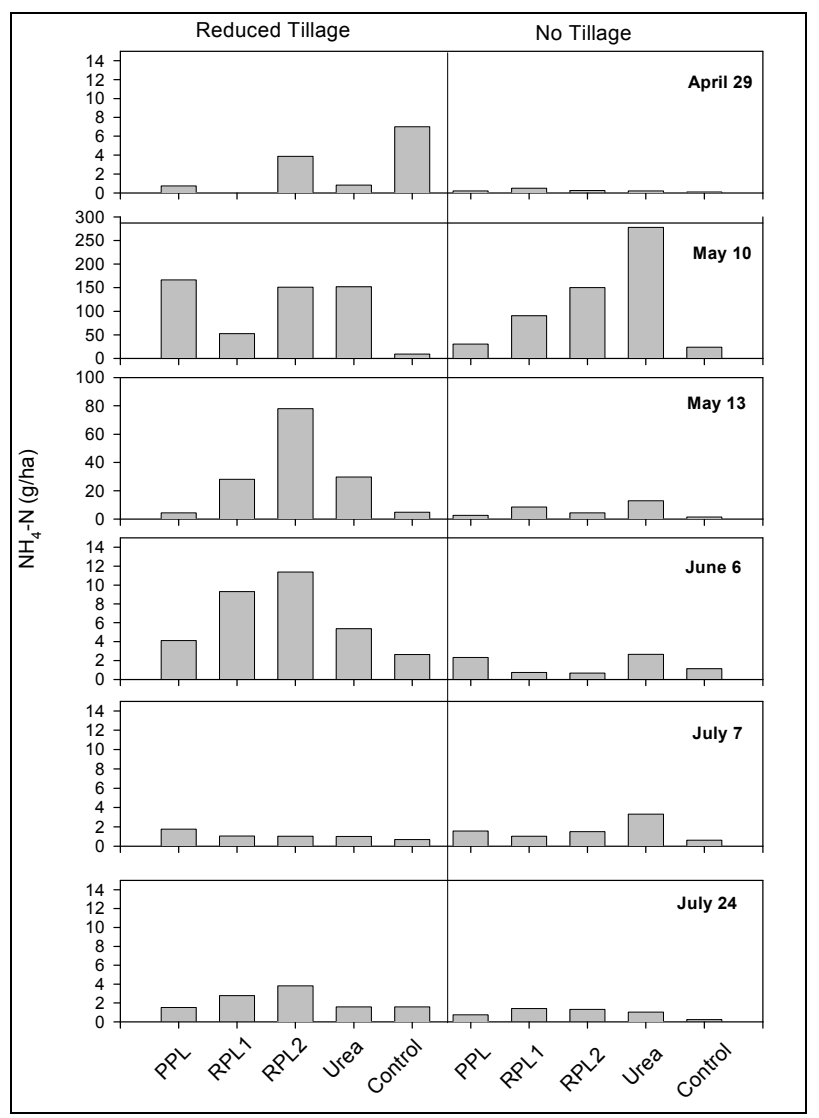

Figure 2. Average mass exports of $\mathrm{NH}_{4}-\mathrm{N}$ for the six storm events from the various treatments.

June 6 and July 24) of the six events (Figures 2-7). Exports from urea and RPL plots were higher than PPL treatments for most events except May 10 and July 7. For the large event of May 10, $\mathrm{NH}_{4}-\mathrm{N}$ export from the PPL plot was comparable to the exports from the RPL1 and
RPL2 treatments. In contrast to reduced tillage, $\mathrm{NH}_{4}-\mathrm{N}$ exports from the no-tillage plots were highest from plots receiving urea for four (May 10, May 13, June 6 and July 7) of the six events. However, similar to reduced tillage, $\mathrm{NH}_{4}-\mathrm{N}$ exports in the no-tillage plot with PPL treatment

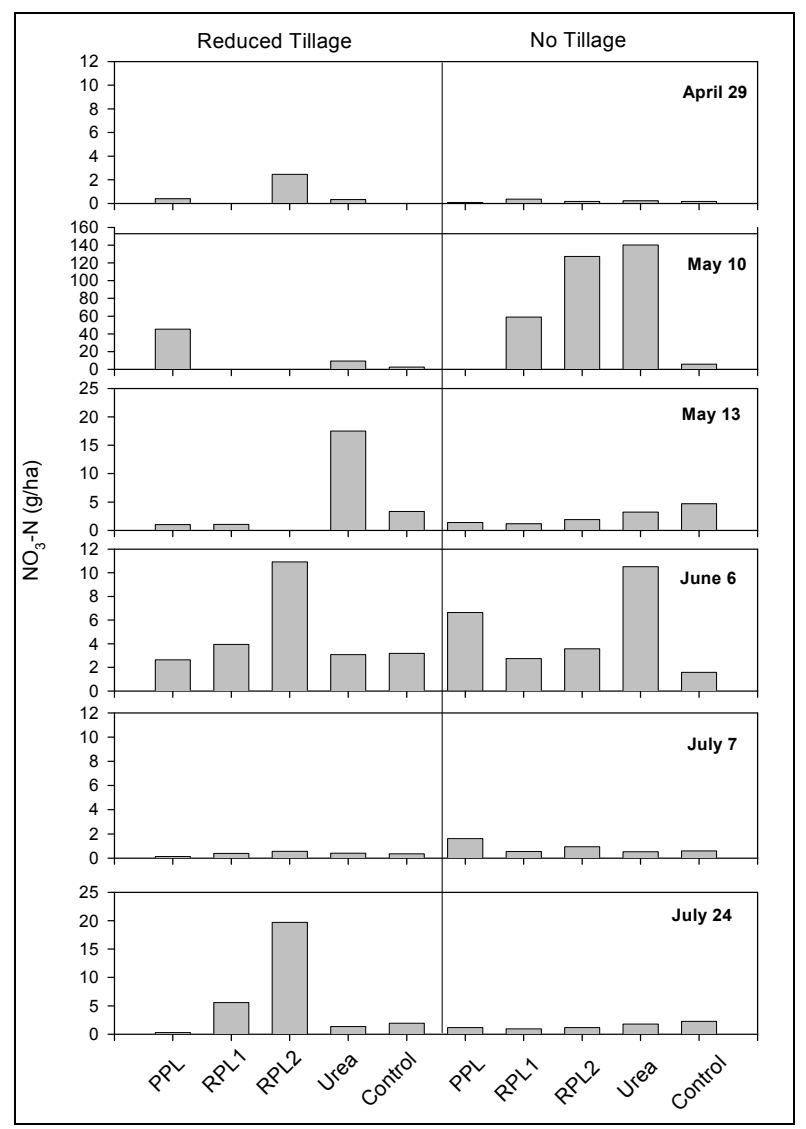

Figure 3. Average mass exports of $\mathrm{NO}_{3}-\mathrm{N}$ for the six storm events from the various treatments. 


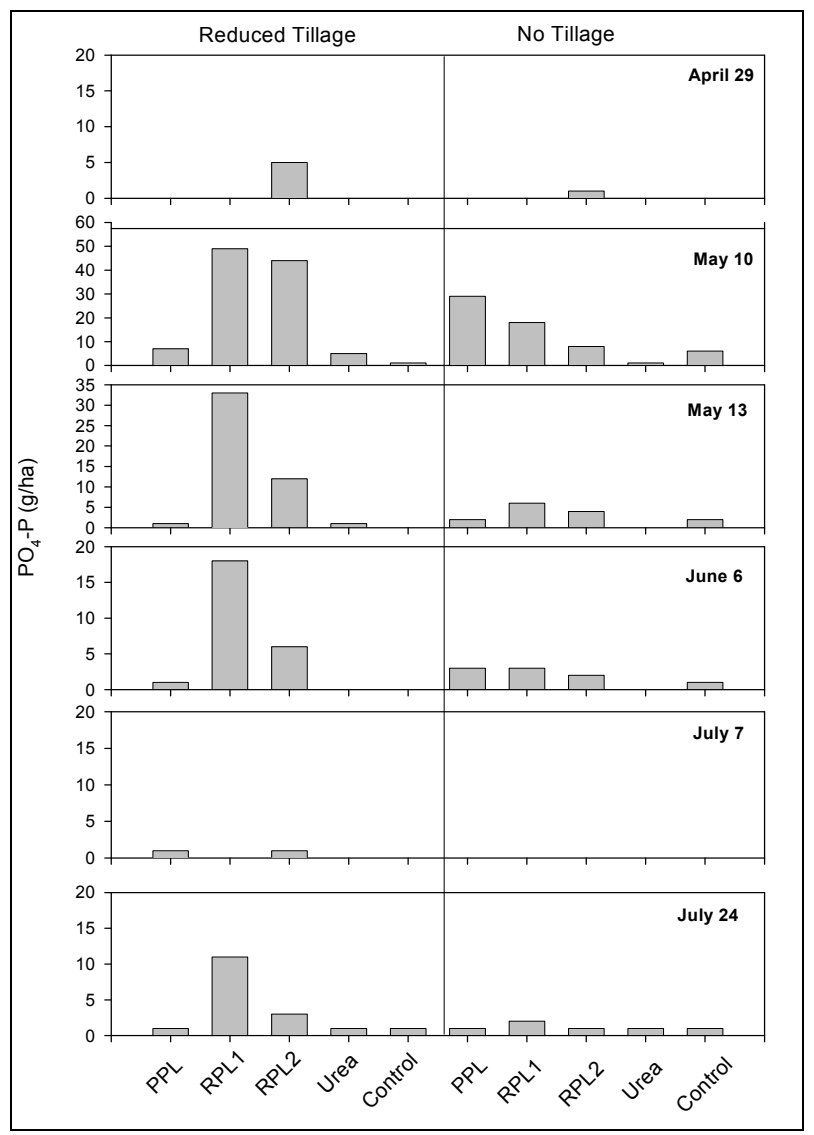

Figure 4. Average mass exports of $\mathrm{PO}_{4}-\mathrm{P}$ for the six storm events from the various treatments.

were again lower than the corresponding values from raw litter and urea treatments for five of the six events.

Similar to $\mathrm{NH}_{4}-\mathrm{N}$, exports of $\mathrm{NO}_{3}-\mathrm{N}$ did not show any significant difference $(p \geq 0.1)$ among the treatment plots; but variations existed during events. Under reduced tillage, the highest exports of $\mathrm{NO}_{3}-\mathrm{N}$ were recorded for RPL2 and urea treatments for all events except the large event of May 10. Surprisingly, the large event of May 10 produced a large amount of $\mathrm{NO}_{3}-\mathrm{N}$ export from the plot receiving PPL application. In comparison, for the notillage practice, $\mathrm{NO}_{3}-\mathrm{N}$ exports decreased in order as Urea $>$ RPL2 $>$ RPL1 for four of the largest events (May 10, May 13, June 6 and July 24). Nitrate exports from the PPL treatment exceeded those from the RPL1, RPL2 and urea treatments for only the smallest event of July 7 for which the export amounts were very low. Except for the RPL2 treatment under no-tillage, the flow-weighted concentrations of $\mathrm{NO}_{3}-\mathrm{N}$ were less than $10 \mathrm{mg} / \mathrm{L}$, which is within the safe limit of $\mathrm{NO}_{3}-\mathrm{N}$ concentration for drinking water [11].

For $\mathrm{PO}_{4}-\mathrm{P}$, there were significant differences $(\mathrm{p} \leq 0.1)$ in mass exports among some of the treatment plots (Table 6). Within reduced tillage, exports of $\mathrm{PO}_{4}-\mathrm{P}$ from PPL treatments were less than the raw litter treatments

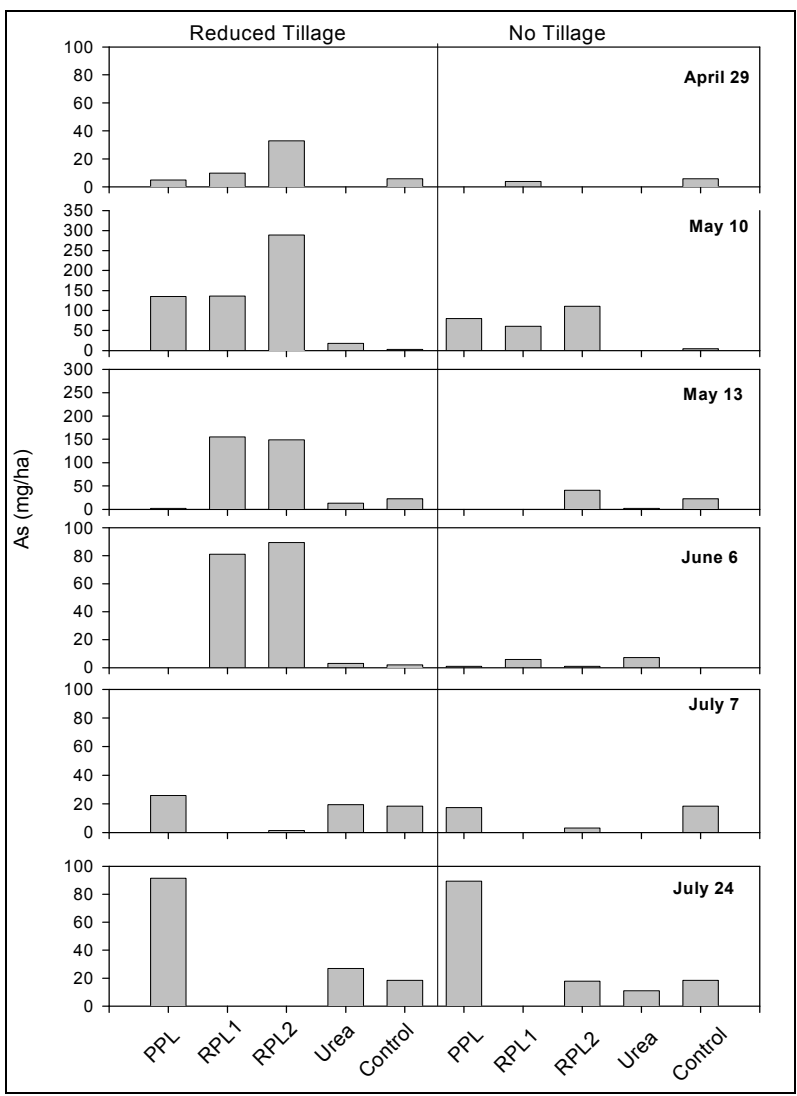

Figure 5. Average mass exports of As for the six storm events from the various treatments.

(RPL1 and RPL2) for the largest five out of the six events (Figures 2-7). While the raw litter treatments produced the largest exports of $\mathrm{PO}_{4}-\mathrm{P}$ it was surprising to note that the treatment with the lower application rate (RPL1) yielded greater $\mathrm{PO}_{4}-\mathrm{P}$ exports. Not surprisingly, the $\mathrm{PO}_{4}-\mathrm{P}$ exports from the urea treated plots were low or negligible since urea treatments did not contain any $\mathrm{P}$. For the no-tillage practice, $\mathrm{PO}_{4}$-P exports from PPL were again lower than comparable exports from raw litter treatments with the exception of the large event of May 10. The large event of May 10 that occurred within a few days of litter application (21 days) resulted in a significant washout of $\mathrm{PO}_{4}$ with surface runoff for the no-tillage plots. The mean flow weighted concentrations of $\mathrm{PO}_{4}-\mathrm{P}$ (Table 6) in surface runoff from raw and pelletized litter treatments were fairly high and much greater than the threshold of $0.1 \mathrm{mg} / \mathrm{L}$ associated with eutrophication in water bodies [12].

In general, mass exports of trace elements ( $\mathrm{As}, \mathrm{Cu}, \mathrm{Zn}$ ) from the poultry treatments (PPL, RPL1, and RPL2) were higher from the reduced-tilled versus the no-tillage plots. The exports were significantly different $(p \leq 0.10)$ among some of the treatments (Table 6). With the exception of the two July events, exports of as from the PPL treatment under reduced tillage were less than the 


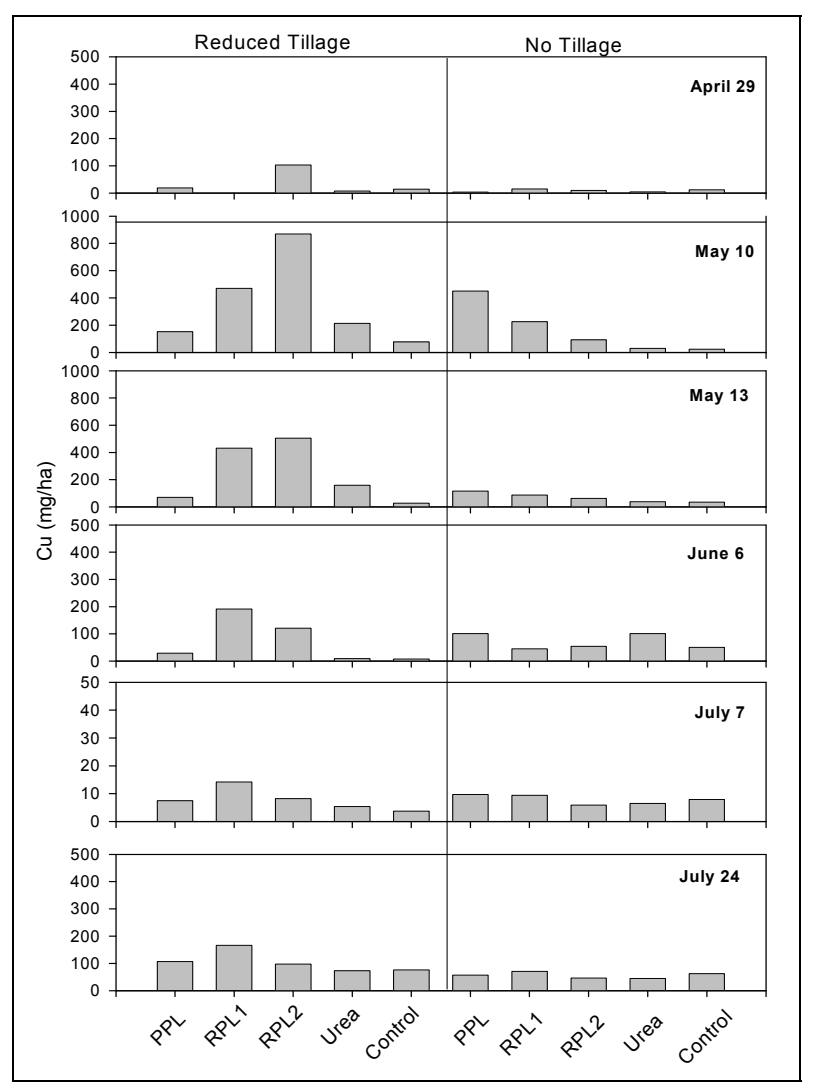

Figure 6. Average mass exports of $\mathrm{Cu}$ for the six storm events from the various treatments.

corresponding values for the raw litter treatment (Figures 2-7). For no-tillage, the exports of As were low and did not reveal any consistent trend. Trace element exports from PPL and RPL were expected to be greater than urea treatments since urea application did not contain trace elements. Similar to the trend with As, exports of both $\mathrm{Cu}$ and $\mathrm{Zn}$ were higher from the raw litter plots versus the PPL plots under reduced tillage. Overall, mass exports of trace elements decreased in the order of RPL $>$ PPL $>$ urea under both tillage practices. The mean flow-weighted concentrations for As (Table 6) from the litter treatments exceeded the drinking water threshold of $0.01 \mathrm{mg} / \mathrm{L}$ [13]. In contrast, the corresponding values for $\mathrm{Cu}$ and $\mathrm{Zn}$ were less of a concern with most being much below the drinking water standards of 1 and $5 \mathrm{mg} / \mathrm{L}$ for $\mathrm{Cu}$ and $\mathrm{Zn}$, respectively [14]. The average mass exports and flowweighted concentrations of DOC were much higher from the RPL treatments versus the PPL and urea treatments. The correlations between exports of DOC and nutrients and trace elements were also significant (Table 8).

\subsection{Impact of Storm Events on the Mass Exports of Nutrients and Trace Elements}

The large exports associated with the large event of May

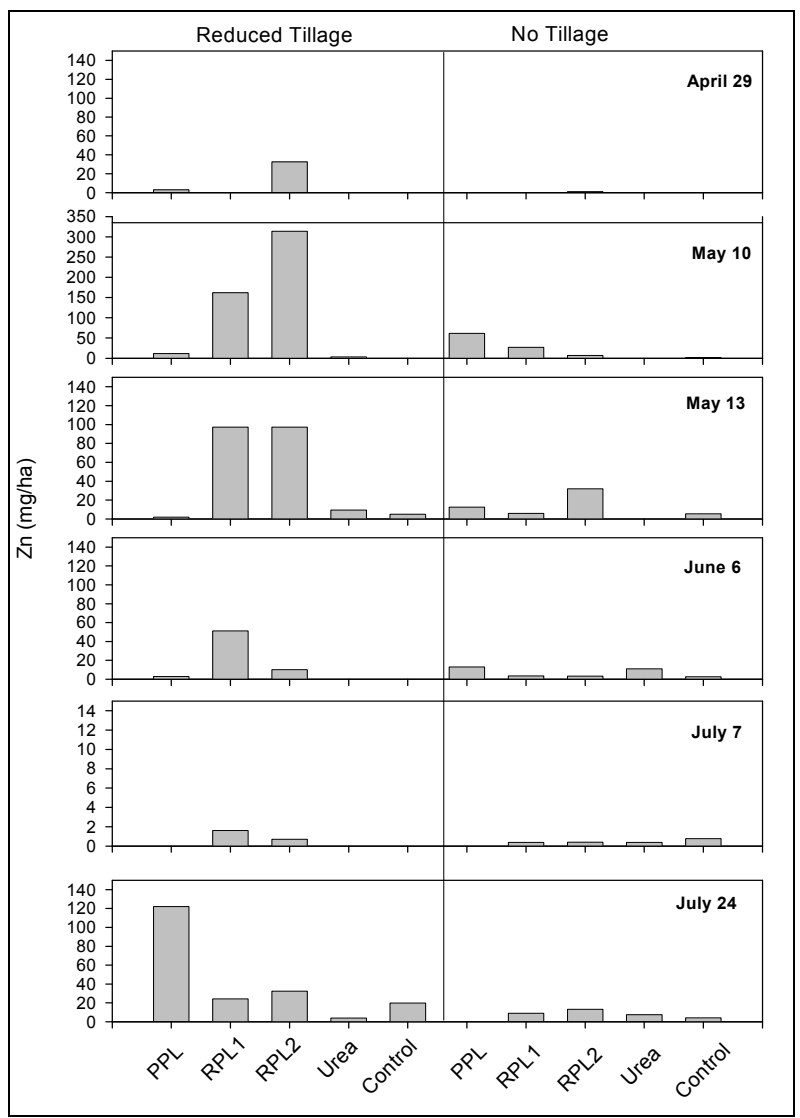

Figure 7. Average mass exports of $\mathrm{Zn}$ for the six storm events from the various treatments.

10 (event 2, Table 1 and Figures 2-7) clearly suggest that the size of the event was an important factor. Significant differences $(p \leq 0.10)$ were also obtained for mass exports of nutrients across the treatment plots at different events. Correlation analysis between rainfall amounts and mass exports of nutrients and trace elements (Table 5) indicated that 17 of the 30 values for reduced tillage and 12 of the 30 values for no-tillage were significantly correlated $(\mathrm{p} \leq 0.10)$. Based on these correlations, it appears that rainfall had a slightly greater impact on mass exports from reduced-tilled plots. Among the correlations, the relationship between rainfall amount and mass export was weakest for $\mathrm{NO}_{3}-\mathrm{N}$. In comparison to rainfall amounts, the correlation between mass exports and the timing of the event (number of days since litter application) was weak (Table 7). The exports decreased with time in most of the cases, but the decrease was not statistically significant ( $\mathrm{p} \geq 0.10)$. Even after 97 days of fertilizer/manure application (event of July 24), mass exports of nutrients and trace elements (As and $\mathrm{Zn}$ ) were observed in the runoff water.

\section{Discussion}

In this section we systematically discuss each of the three 
Table 6. Average mass exports (g/ha) and flow-weighted concentrations (mg/L; within parentheses) for the various treatments (tillage $\times$ fertilization).

\begin{tabular}{|c|c|c|c|c|c|c|c|c|c|c|}
\hline \multirow{2}{*}{$\begin{array}{l}\text { Constituents } \\
\text { monitored }\end{array}$} & \multicolumn{5}{|c|}{ Reduced Tillage } & \multicolumn{5}{|c|}{ No Tillage } \\
\hline & PPL & RPL1 & RPL2 & Urea & Control & PPL & RPL1 & RPL2 & Urea & Control \\
\hline $\mathrm{NH}_{4}-\mathrm{N}$ & $\begin{array}{c}29.9 \\
(13.2)\end{array}$ & $\begin{array}{l}15.7 \\
(2.9)\end{array}$ & $\begin{array}{l}41.5 \\
(7.2)\end{array}$ & $\begin{array}{l}31.8 \\
(8.8)\end{array}$ & $\begin{array}{c}4.4 \\
(1.5)\end{array}$ & $\begin{array}{l}6.3 \\
(2.3)\end{array}$ & $\begin{array}{l}17.1 \\
(8.6)\end{array}$ & $\begin{array}{c}26.4 \\
(13.4)\end{array}$ & $\begin{array}{c}49.6 \\
(10.9)\end{array}$ & $\begin{array}{c}4.6 \\
(1.0)\end{array}$ \\
\hline $\mathrm{NO}_{3}-\mathrm{N}$ & $\begin{array}{c}8.3 \\
(3.7)\end{array}$ & $\begin{array}{c}1.8 \\
(0.3)\end{array}$ & $\begin{array}{c}5.6 \\
(1.0)\end{array}$ & $\begin{array}{c}5.3 \\
(1.5)\end{array}$ & $\begin{array}{l}1.9 \\
(0.7)\end{array}$ & $\begin{array}{c}1.8 \\
(0.7)\end{array}$ & $\begin{array}{l}10.8 \\
(5.4)\end{array}$ & $\begin{array}{c}22.5 \\
(11.4)\end{array}$ & $\begin{array}{l}26.1 \\
(5.7)\end{array}$ & $\begin{array}{c}2.5 \\
(0.6)\end{array}$ \\
\hline $\mathrm{PO}_{4}-\mathrm{P}$ & $\begin{array}{l}2.5^{\mathrm{ab}} \\
(1.1)\end{array}$ & $\begin{array}{c}18.6^{\text {acd }} \\
(3.5)\end{array}$ & $\begin{array}{l}11.8 \\
(2.0)\end{array}$ & $\begin{array}{l}1.4^{\mathrm{c}} \\
(0.4)\end{array}$ & $\begin{array}{l}0.4^{\text {bd }} \\
(0.1)\end{array}$ & $\begin{array}{c}5.9 \\
(2.2)\end{array}$ & $\begin{array}{l}4.9 \\
(2.5)\end{array}$ & $\begin{array}{c}2.6 \\
(1.3)\end{array}$ & $\begin{array}{c}0.5 \\
(0.1)\end{array}$ & $\begin{array}{l}1.6 \\
(0.4)\end{array}$ \\
\hline Arsenic & $\begin{array}{c}0.04 \\
(0.02)\end{array}$ & $\begin{array}{c}0.06 \\
(0.01)\end{array}$ & $\begin{array}{c}0.09 \\
(0.02)\end{array}$ & $\begin{array}{l}0.01^{\mathrm{a}} \\
(0.00)\end{array}$ & $\begin{array}{c}0.01 \\
(0.00)\end{array}$ & $\begin{array}{c}0.03 \\
(0.01)\end{array}$ & $\begin{array}{c}0.02 \\
(0.01)\end{array}$ & $\begin{array}{c}0.03 \\
(0.02)\end{array}$ & $\begin{array}{l}0.03^{\mathrm{ab}} \\
(0.00)\end{array}$ & $\begin{array}{c}0.01^{\mathrm{b}} \\
(0.00)\end{array}$ \\
\hline Copper & $\begin{array}{c}0.06 \\
(0.03)\end{array}$ & $\begin{array}{c}0.21^{\mathrm{a}} \\
(0.04)\end{array}$ & $\begin{array}{c}0.28 \\
(0.05)\end{array}$ & $\begin{array}{c}0.08 \\
(0.02)\end{array}$ & $\begin{array}{c}0.03^{\mathrm{a}} \\
(0.01)\end{array}$ & $\begin{array}{c}0.12 \\
(0.05)\end{array}$ & $\begin{array}{c}0.08 \\
(0.04)\end{array}$ & $\begin{array}{c}0.05 \\
(0.02)\end{array}$ & $\begin{array}{c}0.04 \\
(0.01)\end{array}$ & $\begin{array}{c}0.03 \\
(0.01)\end{array}$ \\
\hline Zinc & $\begin{array}{c}0.02 \\
(0.01)\end{array}$ & $\begin{array}{l}0.06^{\mathrm{ab}} \\
(0.01)\end{array}$ & $\begin{array}{c}0.08 \\
(0.01)\end{array}$ & $\begin{array}{l}0.03^{\mathrm{a}} \\
(0.00)\end{array}$ & $\begin{array}{c}0.04 \\
(0.00)\end{array}$ & $\begin{array}{c}0.01 \\
(0.00)\end{array}$ & $\begin{array}{l}0.01^{\mathrm{b}} \\
(0.00)\end{array}$ & $\begin{array}{c}0.01 \\
(0.01)\end{array}$ & $\begin{array}{c}0.00 \\
(0.00)\end{array}$ & $\begin{array}{c}0.00 \\
(0.00)\end{array}$ \\
\hline DOC & $\begin{array}{c}16 \\
(6.29)\end{array}$ & $\begin{array}{c}116 \\
(16.70)\end{array}$ & $\begin{array}{c}159 \\
(21.11)\end{array}$ & $\begin{array}{c}33 \\
(7.62)\end{array}$ & $\begin{array}{c}9 \\
(2.57)\end{array}$ & $\begin{array}{c}39 \\
(12.12)\end{array}$ & $\begin{array}{c}21 \\
(8.74)\end{array}$ & $\begin{array}{c}28 \\
(11.98)\end{array}$ & $\begin{array}{c}35 \\
(5.97)\end{array}$ & $\begin{array}{c}46 \\
(7.84)\end{array}$ \\
\hline
\end{tabular}

Mass exports having same letters are statistically significantly different at $\mathrm{p} \leq 0.10$. Flow-weighted concentrations were mentioned within parentheses.

Table 7. Correlation (Pearson's) between mass exports of nutrients and trace elements and the time of occurrence of the event (days after litter application) for the six events.

\begin{tabular}{|c|c|c|c|c|c|c|c|c|c|c|}
\hline \multirow{2}{*}{$\begin{array}{l}\text { Constituents } \\
\text { Monitored }\end{array}$} & \multicolumn{5}{|c|}{ Reduced Tillage } & \multicolumn{5}{|c|}{ No Tillage } \\
\hline & PPL & RPL1 & RPL2 & Urea & Control & PPL & RPL1 & RPL2 & Urea & Control \\
\hline $\mathrm{NH}_{3}-\mathrm{N}$ & $\begin{array}{l}-0.29 \\
(0.48)\end{array}$ & $\begin{array}{c}0.22 \\
(0.32)\end{array}$ & $\begin{array}{c}0.28 \\
(0.29)\end{array}$ & $\begin{array}{l}-0.15 \\
(0.39)\end{array}$ & $\begin{array}{l}0.81 * \\
(0.03)\end{array}$ & $\begin{array}{l}-0.29 \\
(0.48)\end{array}$ & $\begin{array}{l}-0.26 \\
(0.45)\end{array}$ & $\begin{array}{l}-0.29 \\
(0.42)\end{array}$ & $\begin{array}{l}-0.28 \\
(0.47)\end{array}$ & $\begin{array}{l}-0.28 \\
(0.47)\end{array}$ \\
\hline $\mathrm{NO}_{3}-\mathrm{N}$ & $\begin{array}{l}-0.28 \\
(0.47)\end{array}$ & $\begin{array}{c}0.55 \\
(0.15)\end{array}$ & $\begin{array}{c}0.55 \\
(0.15)\end{array}$ & $\begin{array}{c}0.14 \\
(0.35)\end{array}$ & $\begin{array}{l}-0.49 \\
(0.84)\end{array}$ & $\begin{array}{l}-0.44 \\
(0.70)\end{array}$ & $\begin{array}{l}-0.30 \\
(0.49)\end{array}$ & $\begin{array}{l}-0.30 \\
(0.49)\end{array}$ & $\begin{array}{c}0.00 \\
(0.48)\end{array}$ & $\begin{array}{l}-0.29 \\
(0.54)\end{array}$ \\
\hline $\mathrm{PO}_{4}-\mathrm{P}$ & $\begin{array}{l}-0.35 \\
(0.54)\end{array}$ & $\begin{array}{l}-0.17 \\
(0.41)\end{array}$ & $\begin{array}{l}-0.22 \\
(0.33)\end{array}$ & $\begin{array}{l}-0.40 \\
(0.59)\end{array}$ & $\begin{array}{l}-0.36 \\
(0.55)\end{array}$ & $\begin{array}{l}-0.39 \\
(0.48)\end{array}$ & $\begin{array}{l}-0.10 \\
(0.38)\end{array}$ & $\begin{array}{l}-0.26 \\
(0.30)\end{array}$ & $\begin{array}{l}-0.39 \\
(0.60)\end{array}$ & $\begin{array}{l}-0.28 \\
(0.47)\end{array}$ \\
\hline Arsenic & $\begin{array}{l}-0.46 \\
(0.73)\end{array}$ & $\begin{array}{c}0.42 \\
(0.22)\end{array}$ & $\begin{array}{c}0.45 \\
(0.20)\end{array}$ & $\begin{array}{c}0.60 \\
(0.12)\end{array}$ & $\begin{array}{c}0.17 \\
(0.35)\end{array}$ & $\begin{array}{l}-0.20 \\
(0.42)\end{array}$ & $\begin{array}{l}-0.21 \\
(0.42)\end{array}$ & $\begin{array}{l}-0.29 \\
(0.48)\end{array}$ & $\begin{array}{c}0.54 \\
(0.16)\end{array}$ & $\begin{array}{l}-0.10 \\
(0.38)\end{array}$ \\
\hline Copper & $\begin{array}{l}-0.50 \\
(0.91)\end{array}$ & $\begin{array}{l}-0.30 \\
(0.48)\end{array}$ & $\begin{array}{c}0.35 \\
(0.26)\end{array}$ & $\begin{array}{l}-0.31 \\
(0.50)\end{array}$ & $\begin{array}{l}-0.47 \\
(0.79)\end{array}$ & $\begin{array}{l}-0.27 \\
(0.46)\end{array}$ & $\begin{array}{l}-0.36 \\
(0.55)\end{array}$ & $\begin{array}{l}-0.40 \\
(0.61)\end{array}$ & $\begin{array}{l}-0.48 \\
(0.80)\end{array}$ & $\begin{array}{l}-0.11 \\
(0.39)\end{array}$ \\
\hline Zinc & $\begin{array}{c}0.56 \\
(0.14)\end{array}$ & $\begin{array}{c}0.10 \\
(0.37)\end{array}$ & $\begin{array}{c}0.16 \\
(0.35)\end{array}$ & $\begin{array}{l}-0.46 \\
(0.75)\end{array}$ & $\begin{array}{c}0.51 \\
(0.17)\end{array}$ & $\begin{array}{c}0.10 \\
(0.38)\end{array}$ & $\begin{array}{l}-0.44 \\
(0.69)\end{array}$ & $\begin{array}{l}-0.48 \\
(0.83)\end{array}$ & $\begin{array}{c}0.58 \\
(0.34)\end{array}$ & $\begin{array}{l}-0.43 \\
(0.67)\end{array}$ \\
\hline
\end{tabular}

The $\mathrm{p}$-values are mentioned within parentheses and numbers indicated by * are significant at $\mathrm{p} \leq 0.10$.

Table 8. Correlation (Pearson's) between mass exports of nutrients and trace elements and the mass exports of DOC in surface runoff.

\begin{tabular}{ccccccc}
\hline Elements & $\mathrm{NH}_{3}-\mathrm{N}$ & $\mathrm{NO}_{3}-\mathrm{N}$ & $\mathrm{PO}_{4}-\mathrm{P}$ & $\mathrm{As}$ & $\mathrm{Cu}$ & $\mathrm{Zn}$ \\
\hline R value & $0.51^{*}(0.00)$ & $-0.10(0.40)$ & $0.83^{*}(0.00)$ & $0.88^{*}(0.00)$ & $0.94 *(0.00)$ & $0.87^{*}(0.00)$ \\
\hline
\end{tabular}

The $\mathrm{p}$-values are mentioned within parenthesis and numbers indicated by $*$ are significant at $\mathrm{p} \leq 0.10$.

questions we raised earlier in the Introduction section of this paper.

\subsection{Impact of Litter Versus Urea on Water Quality}

Overall, urea and RPL treatments yielded higher $\mathrm{NH}_{4}-\mathrm{N}$ exports than PPL for both reduced and no-tillage practices. While comparing inorganic fertilizer versus raw litter, Nichols et al. [5] found that $\mathrm{NH}_{4}-\mathrm{N}$ exports in sur- face runoff from plots receiving inorganic fertilizer (N-P-K mixture + ammonium nitrate) were greater than plots receiving poultry litter. The $\mathrm{NH}_{4}-\mathrm{N}$ exports were 3.7 and $2.1 \mathrm{~kg} / \mathrm{ha}$ for surface-applied and incorporated (rotary tilled) conditions, respectively whereas corresponding values for poultry litter applications were 1.2 and $0.8 \mathrm{~kg} / \mathrm{ha}$. The larger exports of $\mathrm{NH}_{4}-\mathrm{N}$ from urea versus litter applications maybe associated with the greater solubility [15] and mineralization potential [16] of $\mathrm{NH}_{4}-\mathrm{N}$ derived from inorganic fertilizer as opposed to 
raw litter. Pelletized litter has been observed to take even longer time to mineralize compared to raw manure [17]. Similarly, $\mathrm{NO}_{3}-\mathrm{N}$ exports for RPL and urea treated plots were greater than values for PPL under both reduced and no-tillage. Nichols et al. [5] also reported higher $\mathrm{NO}_{3}-\mathrm{N}$ exports and concentrations from plots receiving inorganic fertilizer versus raw poultry litter. Smith et al. [18] also observed higher $\mathrm{NO}_{3}-\mathrm{N}$ concentration in runoff water from plots treated with urea as opposed to plots with raw poultry litter. The higher $\mathrm{PO}_{4}-\mathrm{P}$ exports from RPL and PPL treatments observed in our study were expected since urea treatments were not expected to contain any $\mathrm{P}$.

Mass exports of trace elements were highest from plots treated with raw litter followed by PPL and urea treatments under both reduced and no-tillage management practices. This trend was not unexpected since our analyses (Table 2) indicated that raw litter had the highest concentrations of trace elements. A previous study by Sauer et al. [7] reported high trace-element exports of 97 and $26 \mathrm{~g} / \mathrm{ha}$ for $\mathrm{Cu}$ and $\mathrm{Zn}$, respectively from fescue grass plots receiving poultry litter application at the rate of $6.7 \mathrm{Mg} / \mathrm{ha}$. In comparison to the values of Sauer et al. [7], the magnitude of our exports of trace elements is considerably lower. This may be due to the fact that Sauer et al. [7] recorded the mass exports one day after application whereas our first event occurred after a period of 11 days after litter application and the remaining events occurred over a four-month period. Adsorption to the soil particles or complexation with organic matter [19] may reduce the exports of $\mathrm{Cu}$ and $\mathrm{Zn}$ with surface runoff. Our observations also suggested that the exports of trace elements were strongly correlated with DOC. The elevated exports of DOC from the raw litter plots (especially under reduced tillage, Table 6) would also explain the elevated exports of trace elements from these treatments.

\subsection{Influence of Tillage (Reduced Versus No-Tillage) on Water Quality}

When tillage practices are compared, they appear to have the great impact on the exports of $\mathrm{NH}_{4}-\mathrm{N}, \mathrm{NO}_{3}-\mathrm{N}, \mathrm{PO}_{4}-\mathrm{P}$ and the trace elements. We found higher $\mathrm{NH}_{4}-\mathrm{N}$ exports from the reduced-tilled plots for four of the six events. We believe this may be associated with the history of conventional tillage for our reduced tillage plots. Prior to 2008, these plots were tilled twice a year and may have likely developed an impermeable layer below the tillage depth which may consequently have enhanced the runoff potential for these plots [20]. Elevated exports from conventionally-tilled plots have previously been reported by Seta et al. [21] who reported $57 \%$ less $\mathrm{NH}_{4}-\mathrm{N}$ loss from no-tillage plots versus plots with conventional tillage. They attributed this difference in $\mathrm{NH}_{4}-\mathrm{N}$ exports to the higher amount of runoff and sediment loss from the conventionally-tilled plots. Similarly, Nichols et al. [5] also reported higher $\mathrm{PO}_{4}-\mathrm{P}$ exports from rotary tilled plots versus plots with surface application for both inorganic fertilizer and manure treatments. Phosphate exports from inorganic fertilizer application were 2.6 and 1.8 $\mathrm{kg} / \mathrm{ha}$ for tilled and no-tilled conditions, respectively, whereas the corresponding values for manure were 0.9 and $0.8 \mathrm{~kg} / \mathrm{ha}$.

Interestingly, in our study, the mass exports of trace elements were higher from the reduced-tillage versus the no-tillage plots. This trend was applicable across of the events and treatments. Previous studies have reported an increase in concentrations of As in soil [22-24] as well as runoff waters $[25,26]$ as a result of application of raw poultry litter. However, not much work has been conducted to investigate the impact of tillage practices on trace element exports from plots receiving poultry litter.

\subsection{Impact of Storm Events on Water Quality}

Our results clearly suggest that rainfall amounts influenced the mass exports. Correlations between rainfall amounts and mass exports were strongest for $\mathrm{PO}_{4}-\mathrm{P}$ and trace elements, followed by $\mathrm{NH}_{4}-\mathrm{N}$ and weakest for $\mathrm{NO}_{3}-\mathrm{N}$ (Table 5). Similar observations have been reported in previous studies. Edwards and Daniel [3] found that the exports of $\mathrm{NH}_{4}-\mathrm{N}$ increased from 16.2 to 42.1 $\mathrm{kg} / \mathrm{ha}$ when the simulated rainfall intensity was increased from $5 \mathrm{~cm} / \mathrm{h}$ to $10 \mathrm{~cm} / \mathrm{h}$. They also reported a similar increase in $\mathrm{PO}_{4}-\mathrm{P}$ exports for the same level of increase in rainfall intensity. But, in contrast, rainfall intensity did not have any effect on the exports of $\mathrm{NO}_{3}-\mathrm{N}$ due to infiltration.

We did not find any correlation between the mass exports of nutrients and metals and the timing of the events (days since application of litter). This suggests that concentrations of nutrients or trace elements in runoff did not necessarily decrease or change with time. This result is in contrast with other studies that have found a decrease in $\mathrm{NH}_{4}-\mathrm{N}$ concentrations with time since application $[6,7,27]$. The decrease in $\mathrm{NH}_{4}-\mathrm{N}$ exports was attributed to the loss of $\mathrm{NH}_{4}-\mathrm{N}$ to volatilization, uptake by plants and microorganisms, and oxidation to nitrate. However, as opposed to our study, the studies of Sauer et al. [7] and Sharpley [27] were conducted over a short period of time (1-15 days), received the same amount of simulated rainfall which resulted in almost the same amount of runoff per event. Pierson et al. [6] reported that dissolved reactive $\mathrm{P}$ concentrations decreased linearly with a natural logarithm of time for a study that extended over a period of two years. Sauer et al. [7] also observed a decrease in SRP exports at 14 versus 1 day from plots receiving applications of poultry litter. How- 
ever, we observed increase in $\mathrm{NH}_{4}-\mathrm{N}$ exports from reduced tilled RPL plots in late events like June 6.

Previous studies investigating the influence of time on exports of trace elements have yielded mixed results. Moore et al. [26] evaluated pasture subjected to poultry litter applications and found that the export of $\mathrm{Cu}$ in surface runoff on the seventh day was less than that recorded after the first day of litter application. However, the same pattern did not extend to $\mathrm{Zn}$, where the export on the $7^{\text {th }}$ day was greater than that recorded for the first day after application.

\section{Conclusions}

Overall, this study suggests that the potential for exports of nutrients $\left(\mathrm{NH}_{4}-\mathrm{N}, \mathrm{NO}_{3}-\mathrm{N}, \mathrm{PO}_{4}-\mathrm{P}\right)$ from plots receiving pelletized litter is less than that from raw litter and urea. These results suggest that PPL may be a more environmentally-sound and viable alternative to urea. While the exports of trace elements from PPL were greater than urea, they were still very low and less than the values recorded for raw poultry litter. Thus, among the litter forms, PPL appears to be a better choice to reduce the level of trace elements in surface runoff. Our results also suggest no-tillage management practice can further improve runoff water quality.

\section{Acknowledgements}

Funding for this study was provided through a USDA Conservation Innovation Grant (CIG) and a fellowship to Sudarshan Dutta by the Institute of Soil and Environmental Quality (ISEQ) and the Avian Bioscience Center (ABC) at the University of Delaware. We would like to thank the St. Andrews School at Middletown, Delaware and the farmers for providing access to the agricultural plots. We would also like to recognize the support of Nathan Kiracofe, Dr. Jim Glancey, Nina Finger and Amit Katiyar with experimental plot setup and sampling.

\section{References}

[1] M. E. López-Mosquera, F. Cabaleiro, M. J. Sainz, A. López-Fabal and E. Carral, "Fertilizing Value of Broiler Litter: Effects of Drying and Pelletizing," Bioresource Technology, Vol. 99, No. 13, September 2008, pp. 56265633.

[2] J. T. Sims and D. C. Wolf, "Poultry Waste Management: Agricultural and Environmental Issues," Advances in Agronomy, Vol. 52, 1994, pp. 1-82.

[3] D. R. Edwards and T. C. Daniel, "Effects of Poultry Litter Application Rate and Rainfall Intensity on Quality of Runoff from Fescuegrass Plots," Journal of Environmental Quality, Vol. 22, No. 2, April 1993, pp. 361-365.
[4] B. E. Haggard, P. B. DeLaune, D. R. Smith and P. A. Moore, "Nutrient and 317 -Estradiol Loss in Runoff Water from Poultry Litters," Journal of the American Water Resources Association, Vol. 41, No. 2, April 2005, pp. 245-256.

[5] D. J. Nichols, T. C. Daniel and D. R. Edwards, "Nutrient Runoff from Pasture after Incorporation of Poultry Litter or Inorganic Fertilizer," Soil Science Society of America Journal, Vol. 58, No. 4, July 1994, pp. 1224-1228.

[6] S. T. Pierson, M. L. Cabrera, G. K. Evanylo, H. A. Kuykendall, C. S. Hoveland, M. A. McCann and L. T. West, "Phosphorus and Ammonium Concentrations in Surface Runoff from Grasslands Fertilized with Broiler Litter," Journal of Environmental Quality, Vol. 30, No. 5, September 2001, pp. 1784-1789.

[7] T. J. Sauer, T. C. Daniel, P. A. Moore, K. P. Coffey, D. J. Nichols and C. P. West, "Poultry Litter and Grazing Animal Waste Effects on Runoff Water Quality," Journal of Environmental Quality, Vol. 28, No. 3, May 1999, pp. 860-865.

[8] United States Department of Agriculture, Official Soil Series Description, Washington, D.C., 2004. http://ortho. ftw.nrcs.usda.gov/cgi-bin/osd/osdname.cgi

[9] United States Department of Agriculture Soil Conservation Service and Delaware Agricultural Experiment Station, "Soil Survey, New Castle County, Delaware," October 1970, pp. 92-94.

[10] Delaware Environmental Observing System, "Current Conditions Data Retrieval: Townsend 2008," 2008. http://www.deos.udel.edu/current_retrieval.html

[11] United States Environmental Protection Agency, "Consumer Factsheet on: Nitrates/Nitrites," Washington, D.C. 1992. http://www.epa.gov/safewater/dwh/c-ioc/nitrates.html

[12] North Carolina State University Water Quality Group, "Phosphorous," 2003. http://www.water.ncsu.edu/water shedss/info/phos.html

[13] United States Environmental Protection Agency, "Arsenic in Drinking Water: Basic information," Washington, D.C., 1992. http://www.epa.gov/safewater/arsenic/basic information.html

[14] United States Environmental Protection Agency, "Secondary Drinking Water Regulations: Guidance for Nuisance Chemicals," Washington, D.C., 1992. http://www. epa.gov/safewater/consumer/2ndstandards.html

[15] D. H. Franklin, M. L. Cabrera and V. H. Calvert, "Fertilizer Source and Soil Aeration Effects on Runoff Volume and Quality," Soil Science Society of America Journal, Vol. 70, No. 1, January 2006, pp. 84-89.

[16] F. C. Thornton, N. J. Surpali, B. R. Bock and K. C. Reddy, " $\mathrm{N}_{2} \mathrm{O}$ and $\mathrm{NO}$ Emissions from Poultry Litter and Urea Applications to Bermuda Grass," Atmospheric Environment, Vol. 32, No. 9, May 1998, pp. 1623-1630.

[17] C. M. Hamilton and J. T. Sims, "Nitrogen and Phosphorous Availability in Enriched, Palletized Poultry Litters," Journal of Sustainable Agriculture, Vol. 5, No. 3, June 1995, pp. 115-132. 
[18] D. R. Smith, P. R. Owens, A. B. Leytem and E. A. Warnemuende, "Nutrient Losses from Manure and Fertilizer Applications as Impacted by Time to First Runoff Event," Environmental Pollution, Vol. 147, No. 1, May 2007, pp. 131-137.

[19] E. H. Brock, Q. M. Ketterings and M. McBride, "Copper and Zinc Accumulation in Poultry and Dairy Manure-Amended Soil," Soil Science, Vol. 171, No. 5, May 2006, pp. 388-399.

[20] R. Lal. "No-tillage Effects on Soil Properties under Different Crops in Western Nigeria," Soil Science Society of America Journal, Vol. 40, No. 5, September 1976, pp. 762-768.

[21] A. K. Seta, R. L. Belvins, W. W. Frye and B. J. Barfield, "Reducing Soil Erosion and Agricultural Chemical Losses with Conservation Tillage," Journal of Environmental Quality, Vol. 22, No. 4, October 1993, pp. 661665.

[22] A. Adeli, K. R. Sistani, H. Tewolde and D. E. Rowe, "Broiler Litter Application Effects on Selected Trace Elements under Conventional and No-till Systems," Soil Science, Vol. 172, No. 5, May 2007, pp. 349-365.

[23] E. E. Codling, R. L. Chaney and C. L. Mulchi, "Effects of Broiler Litter Management Practices on Phosphorus,
Copper, Zinc, Manganese and Arsenic Concentrations in Maryland Coastal Plain Soils," Communications in Soil Science and Plant Analysis, Vol. 39, No. 7-8, April 2008, pp. 1193-1205.

[24] W. L. Kingery, C. W. Wood, D. P. Delaney, J. C. Williams and G. L. Mullins, "Impact of Long-Term Land Application of Broiler Litter on Environmentally Related Soil Properties," Journal of Environmental Quality, Vol. 23, No. 1, January 1994, pp. 139-147.

[25] N. S. Bolan, D. C. Adriano and S. Mahimairaja, "Distribution and Bioavailability of Trace Elements in Livestock and Poultry Manure By-Products," Critical Reviews in Environmental Science and Technology, Vol. 34, No. 3, May 2004, pp. 291-338.

[26] P. A. Moore, T. C. Daniel, J. T. Gilmour, B. R. Shreve, D. R. Edwards and B. H. Wood, "Decreasing Metal Runoff from Poultry Litter with Aluminum Sulfate," Journal of Environmental Quality, Vol. 27, No. 1, January 1998. pp. 92-99.

[27] A. N. Sharpley, "Rainfall Frequency and Nitrogen and Phosphorous Runoff from Soils Amended with Poultry Litter," Journal of Environmental Quality, Vol. 26, No. 4, July 1997, pp. 1127-1132. 